\title{
Challenges and Opportunities for Colombia and China
}

\author{
Luis Diego Monsalve
}

Colombia and China established diplomatic relations on February 7, 1980 and the ties forged in politics, economy and cooperation over more than 40 years have now reached their highest point, demonstrating a true friendship that lasts forever. From the beginning, both countries, regardless of the crisis faced, have shown interest in continuing to strengthen their ties and looking toward a prosperous future.

It is undeniable that when we think about humanity, its history, the conception of nations and also the beginning of an international system based on common goals, rules and multilateralism, we must accept that by default the words change, challenge and opportunity have been the driving forces for development. In this context, today and in recent history, humanity has faced tremendous challenges such as the Great Depression, the First World War, the Second World War and today the COVID-19 pandemic, each of which has reinforced the relationship between countries. In the reality and complexity of today's world, we all wonder what the world will be like in the post-pandemic era. As some experts have said, the Coronavirus is not just a health crisis of immense proportion, it will inevitably result in the restructuring of the global economic order, and in this unprecedented new reality, we will witness a dramatic break with the ways society has traditionally operated. The COVID-19 pandemic is a challenge for the world in all aspects. All the policies adopted by governments around the world to reduce the spread of the virus have had an unprecedented impact on trade, social interaction, education, culture and much more.

However, when we are rethinking global geopolitics and the impact on society, we can clearly state that we are on the right track. Of course, history has shown us that humanity is living its own bumpy road. However, as human beings, we have demonstrated time and again our resilience, and in the case of the relationship between Colombia and China, we can only predict a wonderful prospect.

L. D. Monsalve ( $\square)$

Embassy of the Republic of Colombia to the People's Republic of China, Beijing, China 


\section{A Foundation of Strong Political Ties}

Political exchanges and high-level visits have been the pillar of the evolution of our relationship, with the leaders of both countries sharing positions and agreeing on ways to work together in different areas. Through mechanisms such as political consultations such as the tenth meeting, which took place in November 2020 and allowed both parties to follow up on commitments and agree on new strategies.

On the Chinese side, many personalities and leaders have visited Colombia, including former Minister of Foreign Affairs Huang Hua (1981), the State Councilor and Minister of Foreign Affairs Wang Yi (2017) as well as various ministers in different areas, leaders of the Standing Committee of the National People's Congress of China such as Zhang Dejiang (2014), prime ministers such as Li Keqiang (2015) and presidents before taking office such as Hu Jintao (1999) and Xi Jinping (2009). At the same time, representatives of the Colombian side have made numerous official visits from local authorities to ministers, party members, congressmen and vice presidents. At the highest level, the last five Presidents of Colombia have made State Visits to the People's Republic of China, namely Ernesto Samper (1996), Andrés Pastrana (1999), Álvaro Uribe (2005), Juan Manuel Santos (2012) and Iván Duque (2019).

In July 2019, President Duque made a State Visit to China, traveling to Beijing and Shanghai on his first tour of Asia. He visited only China and it was less than a year since his inauguration, which is considered a milestone in the relationship and resulted in bilateral agreements in which both leaders agreed on a comprehensive strategy for the coming years. During this important event, around eleven agreements were signed in transportation, electronic commerce, justice, agriculture, education and technology.

In this area, we still face some challenges, and we must continue to work and establish a regular and consistent strategy from both parties to promote more regular visits from our leaders. In this spirit, our president extended an invitation to President $\mathrm{Xi}$ Jinping to make a State Visit to our country, which will be the highest-level visit in the history of our bilateral relations, and we hope that it will take place during the president's next tour to Latin America. Of course, once again, the COVID19 pandemic particularly affected the free movement of people around the world and in this case official travel. However, we hope that after all flight and migration restrictions are lifted due to the COVID-19 pandemic, we can make several technical visits by our Vice President, Ministers of Commerce, Agriculture, Science, among others, which will help promote specific areas of cooperation.

Finally, we are working to implement what both leaders agreed to in 2019, regarding the launch of the Colombo China Strategy within the framework of the Belt and Road Initiative. Basically, it will be a roadmap for the coming years with concrete and ambitious goals to deepen the relationship and create a strategic alliance. 


\section{Diverse Exchanges in Commerce and Culture}

Colombia and China are definitely countries full of diversity evident in their varied territories and regions. Consequently, another area in which cooperation and political exchange are being strengthened is between local authorities, for the establishment of sister cities and the development of common agendas based on trade and investment, political dialogue and generation of cultural and educational opportunities. Within this framework, there are agreements and exchanges between AtlánticoJiangsu (2001), Barranquilla-Nanjing (2001), Bogotá-Guangzhou (2016), IbaguéChengdu (2017), Casanare-Ningxia (2018), Neiva-Xi'an (2018), Sucre-Hainan (2019), Cartagena-Qingdao (2019), Bogotá-Chengdu (2019) and many others. The embassy has been working on video conferences with local Colombian authorities to identify opportunities and methods of cooperation. On the other hand, the Ambassador has been developing an active agenda visiting more than 22 provinces to learn more about each one, generate exchanges, present areas of collaboration and intensify exchanges. As concrete results, exclusive offers of scholarships for Colombians have been obtained and recently Antioquia and Fujian signed an agreement to establish a relationship as sister provinces. This is undoubtedly a new approach to the relationship between China and Colombia in a changing context, in which we are empowering local authorities to promote more exchanges and contacts between people to emphasize the importance of mutual understanding.

In trade matters, both countries have a wide range of agreements such as the Trade Cooperation Agreement signed in 1981, which includes a Joint Commission for Trade and Investment, which has held eight meetings, the last one in 2012. Both countries are expected to resume this mechanism and hold new meetings on a regular basis starting this year, proposing new tasks to promote commercial exchanges. Likewise, there was also the Economic Cooperation Agreement signed in 1985, which establishes all the economic cooperation agreements that are signed periodically for the allocation of resources and projects of strategic interest. In addition, there was also the Protocol for the Export of Bananas (2002), which is currently being updated to expand the number of regions able to export; some sanitary and phytosanitary cooperation agreements signed in 2005 , to stimulate collaboration and communication between the health authorities of both countries; a Bilateral Investment Treaty that came into force in 2012; a Protocol for the Export of Avocados that allowed access to this fruit in 2019 during President Duque's visit, as well as a Memorandum of Understanding on Electronic Commerce signed during the same visit, which encourages exchanges in this area by taking advantage of the advances of China and seeking to position Colombian products on different platforms.

The evolution of the economic exchange figures today positions China as Colombia's second trading partner in both imports and exports, in which for 2019, global trade amounted to more than USD 15.5 billion. In other words, we went from exporting around USD 17 million in 1991 to USD 4.5 billion in 2019, which is equivalent to an increase of more than 268 times the initial value. Similarly, in imports, we went from importing USD 8 million in 1991 to around USD 11 billion in 
2019, which is equivalent to 1,375 times the initial value. Unfortunately, last year, we only exported USD 2.7 billion and imported USD 10.3 billion. Despite this downturn, the export of non-mining products, which is our main focus, increased in $31 \%$. Although the progress of trade is evident, we are aware on both sides that the trade deficit must be reduced through the expansion of Colombian exports, and that this can be achieved by ensuring that the two economies complement each other. In addition, from Colombia, the goal is to increase exports, mainly non-mining products, and diversify the export basket, which is currently made up of more than $80 \%$ oil and its derivatives.

In this sense, strategies promoted by different government entities, mainly the Agency for the Promotion of Exports, Tourism and Investment-ProColombia, are identifying ways to expand the presence of Colombian products in the Chinese market, and drive an increase in both volumes and figures. Within these trends, for example, in 2019 Colombia participated in the second China International Import Expo-CIIE, the largest import fair in the world, where the Colombian delegation was led by the Vice Minister of Foreign Trade, Laura Valdivieso, and the president of ProColombia, Flavia Santoro. This was the first time that Colombia participated in this fair, at which it had a number of stands including a national pavilion, a commercial stand for ProColombia and the Colombo China Chamber of Commerce and Investments with nine companies focused on agro-industrial products, two stands for the International Trade Center (ITC), with seven companies (four focused on agro-industrial and three on services); and two stands promoting emeralds. Last year, during the third edition of the fair, Colombian companies also participated with a stand from the agro-industrial sector led by ProColombia and the Colombo-China Chamber of Commerce and Investments, with seven companies focusing on coffee, cocoa, pork and fruit.

As part of our efforts to diversify our export basket, a sector that has been identified as having great potential is fashion, because it offers high-quality products with innovative proposals and exclusive designs. Some important Colombian luxury clothing designs are already available on electronic platforms and boutiques, and there is a physical store for swimsuits in Sanya, the most famous beach destination in China. To promote this sector, ProColombia arranged the participation of 23 companies at China Fashion Week in May 2020, and 13 companies at the Beijing Fashion Week held in September 2020.

Despite all the new realities in terms of the supply chain and logistics, which are a result of the pandemic, the goals in this field are aimed at expanding exports of agricultural products (currently only amounting to $3.5 \%$ ), where Colombia will focus on high-quality products seeking to increase the amount of coffee (green and roasted), fresh and canned flowers, chocolates, bananas and avocados it exports while also gaining access to new tropical fruits such as lemon, passion fruit, mango and pineapple, and products such as beef and pork. Additionally, it is important to position some products such as alcoholic beverages (rum), healthy drinks, haute couture, swimwear and control clothing. To this end, our strategies are focused on stimulating the relationship between health authorities, participation in events, fairs 
and seminars, where Colombia expects to attend as a guest of honor in the fourth China International Import Expo and expand its presence in trade platforms.

China has become Colombia's second trading partner worldwide in terms of both exports and imports, and there have been irrefutable achievements in this area, where we have overcome hurdles like geographical distance, language barriers and differences in laws. However, we still have some important concerns that we need to address: 1. We must reduce the existing trade deficit of around USD 7 billion. 2. We must diversify the export basket (around 90\% is oil and mining), eliminating nontariff barriers and moving faster in the admission process. 3. We must also establish a common strategy to increase the joint promotion of Colombian products in China and facilitate access to new channels such as e-commerce.

Regarding investment flows, there is a Bilateral Investment Treaty to promote bilateral flows. The number of Chinese companies that have settled in Colombia has steadily increased, and today there are more than 80 companies in different sectors such as infrastructure, technology, automotive, renewable energy, oil and gas, mining, among others. The last two years were extraordinary in this area with Chinese companies winning the most important bids for infrastructure projects in Colombia, such as the Bogotá Metro, which is the largest project of its kind in Latin America; Regiotram Railway; several projects in the renewable energy sector, some of which are already in operation; mining; water treatment facilities; hospitals, etc. Considering Colombia's interest in attracting more Chinese investment, the Embassy in Beijing, along with ProColombia, has created an event called "Coffee with the Ambassador" where we periodically present all the opportunities and new projects in the pipeline.

In a recently published analysis, UNCTAD revised its projections on the potential impact of the COVID-19 pandemic on FDI and global supply chains. The update predicts downward pressure on estimated global FDI that, of course, is also affecting the relationship between China and Colombia, mainly in creating new opportunities. However, the Colombian proposals are mainly based on mega investments and largescale projects, and in this sense, we are driving and expanding the benefits for Chinese companies, while also creating events to help them better understand the requirements and procedures. To adapt these new challenges, Colombia has mainly used webinars and online events.

It is clear that the global economy will take another shape after COVID-19, including how investors will view resilience and risk. According to some firms and academics, companies, especially in the manufacturing sector, will reconsider their location footprints and seek to regionalize or localize their production and supply chains to mitigate risk. Companies will have to prioritize supply chain resilience over the current focus on efficiency. Therefore, there will also be other opportunities to explore with China in terms of FDI, taking into account our advantages in the region and the need for companies to ensure a constant supply to consumers, through the adaptation of their production. Colombia is strategically located in the middle of the Americas, enabling us to act as a regional export platform.

Despite the fact that the world is facing a global contraction due to COVID19, Colombia continues to be one of the countries with the best growth projections 
in Latin America. We are the fourth-largest economy in the region and have seen sustained growth in recent years, dynamism and recognized stability. In addition, we have a market of around 50 million people, rooted in a growing middle class with high purchasing power. The Colombian government is dedicated to improving its competitiveness as an engine of economic growth, and in this sense, we offer many incentives to promote FDI. As a result, Colombia has established itself as the third-largest recipient of foreign investment in our region and is among the top 30 countries worldwide. The world showed its confidence and trust in Colombia when we officially became the 37 th member of the OECD.

For this reason, there is also a growing interest of Chinese companies in establishing themselves in Colombia to produce and cover the regional market in sectors such as technology, construction materials, clothing and medical devices. Even though Chinese investment is increasing in Colombia, and currently ranks first among major Asian investors, we are eager to continue exploring new opportunities in these new circumstances. The main challenges are: 1 to continue working closely to promote investment projects and gain a better understanding of local regulations, benefits, and advantages; and 2. to establish better strategies between both countries to promote the transfer of knowledge and technology in order to meet Chinese requirements.

Tourism is also an important sector in which Colombia is expanding its offer, seeking to increase the number of Chinese tourists, which is currently growing at $15 \%$ annually through new marketing strategies such as a special agreement with BAIDU, and webinars with travel agencies, reaching around 21,000 in 2019. Unfortunately, this sector was one of the most affected by the pandemic, and will only restart internationally, and under normal conditions, once COVID-19 is under control and regular flights have resumed. Therefore, we need to add new variables and value to our proposals, linked not only to adapting to the demands of Chinese tourists, but also to an extra component that we are currently working on, biosecurity. Colombia has already taken very strong measures to guarantee safe destinations, and prepared the country so that as our marketing states: We are ready to receive them in the most welcoming place on earth! These days, Colombia offers many new exclusive destinations with unique experiences in terms of bird watching, UNESCO heritage sites, main cities such as Cartagena, attractions of the Coffee Axis and much more.

\section{Exchange and Education}

Cooperation has been one of the most important tools to generate trust and friendship between both countries. In this sense, the framework for cooperation in different fields is the Cooperation Agreement signed in 1981 and some subsidiary agreements signed for specific topics. Since then, different activities have been carried out in agriculture, demining, defense, science and technology, construction, transportation and infrastructure among others. Through donations, courses, seminars, joint 
committees, and visits, both countries have established ambitious projects to share best practices and develop capacities.

In this area, during this year, one of the greatest signs of friendship took place, reaffirming that despite any crisis, we have been committed to each other, confirming that "a friend in need is a friend indeed." During the COVID-19 pandemic, both countries supported the other through donations, especially of personal protective equipment (PPE), in which Chinese donations to Colombia from local governments, the national government and companies, were valued at USD 1.5 million. In this battle, Colombia and China continue to work together, exchanging best practices and knowledge to improve the capacity for control, prevention and treatment. Recently, we continued to cooperate, and Colombia bought Chinese vaccines from the pharmaceutical company SINOVAC, which arrived in Colombia in February 2021, marking an important event for the entire country, in terms of reaffirming the government's commitment to the National Vaccination Plan, as well as a sign of hope for our people. Consequently, there was a very positive environment and it attracted extensive media coverage throughout the process. President Duque, the Vice President and the Chinese Ambassador in Bogotá held a joint press conference at the airport depot to keep the country informed about the successful arrival and distribution in Colombia. This is an important sign of how opportunities open up during a crisis and continue to strengthen the bond between the two countries. Since then, we have received a total of 7.5 million doses.

Another area related to enhancing political understanding and cooperation is culture. Culture creates more personal exchanges and a better mutual understanding that can bring countries closer. To this end, Colombia and China signed a Cultural Agreement in 1981, which includes activities in the arts, music and literature. Over the past 41 years, both countries have carried out different activities that represent their culture including dances such as the famous Barranquilla Carnival as well as performances of salsa and ballet; music ranging from lyrical singers to the best of our folklore; theater such as Chinese opera; cinema with several film festivals; literary activities including the visit of the Chinese Nobel Laureate Mo Yan to Colombia and various activities related to our Colombian Nobel Gabriel García Márquez; visual arts with exhibitions by renowned artists such as the painter and sculptor Fernando Botero; and museum exhibits such as pre-Columbian gold pieces at the Bogotá Gold Museum and a terracotta warriors exhibit at the National Museum of Colombia. Of course, the pandemic also affected this area, but we continue to work to create new opportunities using technology. Recently, we held cultural presentations such as Salsa con Delirio online and the Chinese New Year Gala was broadcast nationwide Colombian television.

In education, every year, more Colombians decide to study in China, and more Chinese students visit Colombia. Within the framework of the agreement signed in 1981, every three years, both countries agree on an implementation plan that includes activities and scholarships. China offers scholarships every year through the China Scholarship Council, the Colombian Institute for Educational Credit and Technical Studies Abroad-ICETEX and the Chinese Embassy in Colombia. Likewise, Colombia grants scholarships to Chinese citizens through ICETEX. Here, it is 
important to note that during the 2020 scholarship call, more than 300 Colombian students applied for the 70 scholarships offered, which shows the interest of Colombian students to study in China. During the last call, and despite the pandemic, more than 60 Colombians applied for 30 scholarships. Consequently, the Embassy is designing a new strategy to access more scholarships through local governments, universities, companies and other sponsors. In addition, many universities have agreed to bilateral student exchange programs to promote joint studies in a multicultural environment. However, we need to create new ways to improve the relationship in education, taking into account that currently there are many restrictions for students to travel abroad, which is why, for example, Chinese universities are providing online courses.

Both countries have also made significant efforts to overcome the language barrier. In particular, Colombia has made Spanish accessible to our Chinese friends through programs like ELE-FOCALAE, through which Chinese students or tour guides receive full scholarships to learn Spanish for four months, a partnership with ICETEX and local universities to through which Colombia welcomed Chinese students to our country to learn Spanish while teaching Chinese language and culture for an academic year, and sent Spanish teachers to China to train public officials. Likewise, China established three Confucius Institutes - two with universities offering classes for enrolled students and beyond: Andes has included high school students in three affiliated classrooms and has reached second-tier cities such as Bucaramanga and Cali and Universidad Jorge Tadeo Lozano, which for two years has partnered with the National Learning Service-SENA, the Colombian public institution in charge of vocational training to bring Chinese to the departments of Atlántico, Bolívar, Caldas and Quindío. A third institute was established by the city of Medellín with EAFIT University and includes nine teaching locations around the city. There is also a Confucius classroom at the Colegio Nueva Granada.

As you will have noticed, the political, economic and cooperation relationships between both countries has been full of challenges, adapting many times to the changing context of the world, but at the same time, there have always been many opportunities. We have been working closely in many fields that are important for the development of each country, to strengthen this true and lasting friendship. The pandemic is just one more challenge that we will also successfully overcome as part of the same human family, based in the spirit of multilateralism and cooperation. Without a doubt, Colombia and China will continue to work together in the face of any obstacles in the future. 


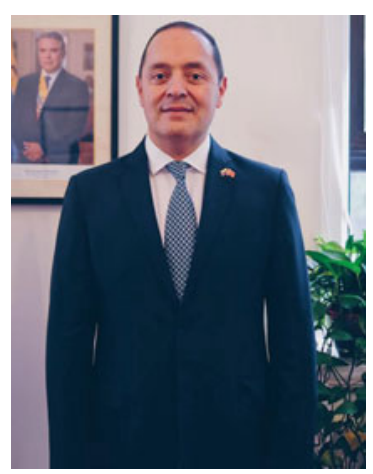

H.E. Mr. Luis Diego Monsalve is the ambassador of the Republic of Colombia to the People's Republic of China. He studied Law at Universidad Bolivariana, obtained an MBA at EAFIT, and a Master in Public Administration at Harvard Kennedy School. He has served as the ambassador of Colombia to China since March 2019. From 2000 to 2019, he was CEO of New Stetic, a producer and trader of Dental and Pharmaceutical Products around the world. Previously, he served as VP of TAMPA Airlines, President of the Colombian Railways and Member of Medellin Council (public election). He also had experience as shareholder and member of the Board of Directors of various companies in different sectors.

Open Access This chapter is licensed under the terms of the Creative Commons AttributionNonCommercial-NoDerivatives 4.0 International License (http://creativecommons.org/licenses/bync-nd/4.0/), which permits any noncommercial use, sharing, distribution and reproduction in any medium or format, as long as you give appropriate credit to the original author(s) and the source, provide a link to the Creative Commons license and indicate if you modified the licensed material. You do not have permission under this license to share adapted material derived from this chapter or parts of it.

The images or other third party material in this chapter are included in the chapter's Creative Commons license, unless indicated otherwise in a credit line to the material. If material is not included in the chapter's Creative Commons license and your intended use is not permitted by statutory regulation or exceeds the permitted use, you will need to obtain permission directly from the copyright holder.

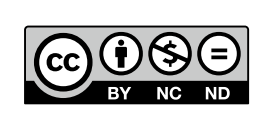

